\title{
Sterigmatocystins from the deep-sea-derived fungus Aspergillus versicolor
}

\author{
Shengxin Cai, Tianjiao Zhu, Lin Du, Boyu Zhao, Dehai Li and Qianqun Gu \\ Three new sterigmatocystin derivatives, oxisterigmatocystin A (1), oxisterigmatocystin B (2) and oxisterigmatocystin C (3), \\ together with one known compound, 5-methoxysterigmatocystin (4), were isolated from the deep-sea-derived fungus Aspergillus \\ versicolor. The structures of the new compounds were elucidated by spectroscopic methods. The cytotoxicities of compounds \\ 1-4 were evaluated against the A-549 and HL-60 cell lines. Compound 4 exhibited moderate cytotoxicities against the A-549 \\ and $\mathrm{HL}-60$ cell lines with $\mathrm{IC}_{50}$ value of 3.86 and $5.32 \mu \mathrm{m}$, respectively.
}

The Journal of Antibiotics (2011) 64, 193-196; doi:10.1038/ja.2010.154; published online 1 December 2010

Keywords: Aspergillus versicolor; deep-sea; fungus; sterigmatocystin

\section{INTRODUCTION}

The fungal genus Aspergillus versicolor has been reported to produce different kinds of bioactive compounds, such as sterigmatocystins, ${ }^{1}$ diketopiperazine alkaloids, ${ }^{2}$ sesquiterpenoids ${ }^{3}$ and cyclopeptides. ${ }^{4}$ Sterigmatocystins, bearing xanthone and bisfuran moieties in their structures, belong to a family of potently cytotoxic xanthones. ${ }^{1}$

In our screening of cytotoxic deep-sea-derived microorganisms, ${ }^{5-9}$ the extract of a fungus strain CXCTD-06-6a, which was obtained from an underwater sample (depth, $800 \mathrm{~m}$ ) and authenticated as A. versicolor, exhibited potent cytotoxicity against the K562 cell line. Chemical investigation on the extract led to the isolation of three new sterigmatocystin derivatives, oxisterigmatocystin A (1), oxisterigmatocystin B (2) and oxisterigmatocystin C (3), together with one known compound, 5-methoxysterigmatocystin (4). ${ }^{10}$ In this paper, we report the isolation, structure elucidation and cyctoxicities of these compounds.

\section{RESULTS AND DISCUSSION}

\section{Structure determination}

Compounds $\mathbf{1}$ and $\mathbf{2}$ were pale yellow needle-like crystals. Their molecular formulas were both determined as $\mathrm{C}_{20} \mathrm{H}_{18} \mathrm{O}_{8}$ based on HR-ESI-MS, indicating 12 degrees of unsaturation. The 1D NMR data of these two compounds (Table 1) contained resonances for one carbonyl, nine quarternary carbons, six methines, one methylene and three methoxyl groups. Careful analysis of 1D NMR data (Table 1) revealed that compound $\mathbf{1}$ bore a similar sterigmatocystin skeleton as that of compound $4 .{ }^{10}$ The only structural difference between compounds 1 and 4 was that the double bond between C- $3^{\prime}$ and $\mathrm{C}-4^{\prime}$ in compound 4 was saturated by methyl alcohol in compound 1 . This conclusion could be confirmed by the COSY and HMBC correlations as shown in Figure 1. Furthermore, the methoxyl group $\left(\delta_{\mathrm{H}} 3.22, \mathrm{~s} ; \delta_{\mathrm{C}}\right.$ $55.2 \mathrm{CH}_{3}$ ) could be assigned at $\mathrm{C}-4^{\prime}$ based on the $\mathrm{HMBC}$ correlation from $4^{\prime}-\mathrm{OMe}(\delta 3.22, \mathrm{~s})$ to $\mathrm{C}-4^{\prime}(\delta 106.8, \mathrm{CH})$ (Figure 2$)$. The ${ }^{1} \mathrm{H}$ - and ${ }^{13} \mathrm{C}-\mathrm{NMR}$ data of compound 2 were almost identical to those of compound 1 except that they had different coupling patterns of $\mathrm{H}-2^{\prime}, \mathrm{H}-3^{\prime}$ and $\mathrm{H}-4^{\prime}$ (Table 1). So compound 2 was proposed as a diastereomer of compound $\mathbf{1}$.

The absolute configurations of compounds $\mathbf{1}$ and $\mathbf{2}$ were determined by comparation of coupling constants, optical rotations and conformational analysis. Large coupling constants between $\mathrm{H}-1^{\prime}$ and $\mathrm{H}-2^{\prime}$ of compounds 1,2 and $4(J=6.0,6.0$ and $7.0 \mathrm{~Hz}$, respectively) suggested cis configuration between these two protons as sterigmatocystin. ${ }^{11}$ In addition, compound 4 and sterigmatocystin ${ }^{11}$ were both levorotatory, suggesting that they had the same absolute configurations $\left(1^{\prime} \mathrm{R}, 2^{\prime} \mathrm{S}\right) .{ }^{11}$ Analyzing the structures of 1,2 and 4 , compounds 1 and 2 were postulated to be biologically transformed by 4 via saturation with methanol, and the process obviously did not affect the configurations of $\mathrm{C}-1^{\prime}$ and $\mathrm{C}-2^{\prime}$. Therefore, the absolute configurations of $\mathrm{C}-1^{\prime}$ and $\mathrm{C}-2^{\prime}$ of compounds 1 and 2 were also assigned as $1^{\prime} \mathrm{R}$ and $2^{\prime} \mathrm{S} .{ }^{11}$ The $\beta$ configuration of $4^{\prime}$-OMe in compound 1 was assigned based on the coupling patterns of $\mathrm{H}-3^{\prime}(\delta 2.40$, ddd, $J=13.7$, 9.1, $5.0 \mathrm{~Hz}, \mathrm{H}-3^{\prime} \mathrm{a}$ and $\left.\delta 2.53, \mathrm{~d}, J=13.7 \mathrm{~Hz}, \mathrm{H}-3^{\prime} \mathrm{b}\right)$ and $\mathrm{H}-4^{\prime}(\delta 5.26$, $\mathrm{d}, J=5.0 \mathrm{~Hz}$ ). As there was no observable coupling between $\mathrm{H}-3^{\prime} \mathrm{b}$ and $\mathrm{H}-4^{\prime}$, the dihedral angel between these two protons should be between $80^{\circ}$ and $100^{\circ}$. The coupling constant of $\mathrm{H}-3^{\prime} \mathrm{a}$ and $\mathrm{H}-4^{\prime}(J=5.0 \mathrm{~Hz})$ suggested the dihedral angel between these two protons was about $40^{\circ}$ (Figure 3a). Similarly, the dihedral angel between $\mathrm{H}-3^{\prime} \mathrm{b}$ and $\mathrm{H}-2^{\prime}$ should be $80^{\circ}-100^{\circ}$, and the angle between $\mathrm{H}-3^{\prime} \mathrm{a}$ and $\mathrm{H}-2^{\prime}$ was close to $20^{\circ}$ (Figure $3 \mathrm{~b}$ ). ${ }^{12}$ For compound 2 , the relative configuration of $4^{\prime}$-OMe should be $\alpha$. However, the coupling constant pattern was not

Key Laboratory of Marine Drugs, Chinese Ministry of Education, School of Medicine and Pharmacy, Ocean University of China, Qingdao, PR China

Correspondence: Dr D Li or Dr Q Gu, Key Laboratory of Marine Drugs, Chinese Ministry of Education, School of Medicine and Pharmacy, Ocean University of China, 5 Yushan Road, Qingdao 266003, PR China.

E-mail: dehaili@ouc.edu.cn or guqianq@ouc.edu.cn

Received 13 July 2010; revised 2 October 2010; accepted 7 November 2010; published online 1 December 2010 
Table $1{ }^{1} \mathrm{H}-(600 \mathrm{MHz})$ and ${ }^{13} \mathrm{C}$ - (150 MHz) NMR data for compounds $1-3$ in $\mathrm{CDCl}_{3}$

\begin{tabular}{|c|c|c|c|c|c|c|}
\hline \multirow[b]{2}{*}{ No. } & \multicolumn{2}{|r|}{$1(\mathrm{~J}$ in $\mathrm{Hz})$} & \multicolumn{2}{|r|}{$2(\mathrm{~J}$ in $\mathrm{Hz})$} & \multicolumn{2}{|r|}{$3(\mathrm{~J}$ in $\mathrm{Hz})$} \\
\hline & $\delta_{C}$ & $\delta_{H}$ & $\delta_{C}$ & $\delta_{H}$ & $\delta_{C}$ & $\delta_{H}$ \\
\hline 1 & 163.5 & & 163.5 & & 162.9 & \\
\hline 2 & 90.3 & $6.37(1 \mathrm{H}, \mathrm{s})$ & 90.6 & $6.40(1 \mathrm{H}, \mathrm{s})$ & 90.7 & $6.61(1 \mathrm{H}, \mathrm{s})$ \\
\hline 3 & 165.0 & & 164.9 & & 165.0 & \\
\hline 4 & 107.9 & & 106.9 & & 107.8 & \\
\hline 5 & 139.5 & & 139.4 & & 106.4 & $6.94(1 \mathrm{H}$, brd, 7.7$)$ \\
\hline 6 & 120.7 & $7.17(1 \mathrm{H}, \mathrm{d}, 9.2)$ & 120.4 & $7.19(1 \mathrm{H}, \mathrm{d}, 9.1)$ & 136.1 & $7.61(1 \mathrm{H}, \mathrm{dd}, 8.2,8.3)$ \\
\hline 7 & 109.4 & $6.67(1 \mathrm{H}, \mathrm{d}, 9.2)$ & 109.5 & $6.69(1 \mathrm{H}, \mathrm{d}, 8.7)$ & 110.7 & $6.73(1 \mathrm{H}, \mathrm{dd}, 8.3,1.1)$ \\
\hline 8 & 155.5 & & 155.2 & & 161.4 & \\
\hline 9 & 181.5 & & 181.3 & & 180.4 & \\
\hline 10 & 153.9 & & 154.3 & & 154.5 & \\
\hline 11 & 109.7 & & 109.5 & & 108.2 & \\
\hline 12 & 105.9 & & 106.0 & & 104.5 & \\
\hline 13 & 145.0 & & 144.7 & & 153.1 & \\
\hline $1-\mathrm{OCH}_{3}$ & 56.8 & $4.00(1 \mathrm{H}, \mathrm{s})$ & 56.8 & $4.00(1 \mathrm{H}, \mathrm{s})$ & & \\
\hline $5-\mathrm{OCH}_{3}$ & 58.0 & $3.91(1 \mathrm{H}, \mathrm{s})$ & 57.7 & $3.91(1 \mathrm{H}, \mathrm{s})$ & 56.7 & $3.89(1 \mathrm{H}, \mathrm{s})$ \\
\hline $1^{\prime}$ & 113.8 & $6.54(1 \mathrm{H}, \mathrm{d}, 6.0)$ & 111.9 & $6.49(1 \mathrm{H}, \mathrm{d}, 6.0)$ & 113.8 & $6.61(1 \mathrm{H}, \mathrm{d}, 6.1)$ \\
\hline $2^{\prime}$ & 42.9 & $4.23(1 \mathrm{H}, \mathrm{dd}, 9.1,6.4)$ & 42.8 & $4.30(1 \mathrm{H}, \mathrm{ddd}, 9.2,5.5,3.7)$ & 41.9 & $4.22(1 \mathrm{H}, \mathrm{dd}, 9.4,6.6)$ \\
\hline $3^{\prime}$ & 37.2 & $\begin{array}{c}\text { a: } 2.40(1 \mathrm{H}, \mathrm{ddd}, 13.7,9.1,5.0) \\
\text { b: } 2.53(1 \mathrm{H}, \mathrm{d}, 13.7)\end{array}$ & 36.8 & $\begin{array}{l}\text { a: } 2.44(1 \mathrm{H}, \mathrm{ddd}, 13.7,8.9,4.7) \\
\text { b: } 2.49(1 \mathrm{H}, \mathrm{ddd}, 13.3,4.4,4.1)\end{array}$ & 36.6 & $\begin{array}{c}\text { a: } 2.41(1 \mathrm{H}, \mathrm{ddd}, 13.2,9.3,4.9) \\
\text { b: } 2.24(1 \mathrm{H}, \mathrm{d}, 13.2)\end{array}$ \\
\hline $4^{\prime}$ & 106.8 & $5.26(1 \mathrm{H}, \mathrm{d}, 5.0)$ & 107.0 & $5.22(1 \mathrm{H}, \mathrm{dd}, 5.0,4.6)$ & 106.2 & $5.27(1 \mathrm{H}, \mathrm{d}, 5.0)$ \\
\hline $4^{\prime}-\mathrm{OCH}_{3}$ & 55.2 & $3.22(3 \mathrm{H}, \mathrm{s})$ & 56.7 & $3.49(3 \mathrm{H}, \mathrm{s})$ & 54.6 & $3.11(3 \mathrm{H}, \mathrm{s})$ \\
\hline $8-\mathrm{OH}$ & & $12.73(1 \mathrm{H}, \mathrm{s})$ & & $12.61(1 \mathrm{H}, \mathrm{s})$ & & $13.40(1 \mathrm{H}, \mathrm{s})$ \\
\hline
\end{tabular}

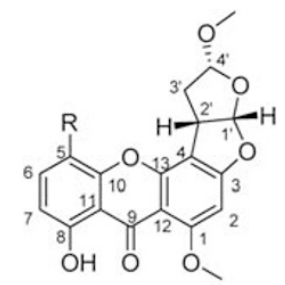

1. $\mathrm{R}=\mathrm{OMe}$

3. $\mathrm{R}=\mathrm{H}$

Figure 1 Structures of compounds $1-4$

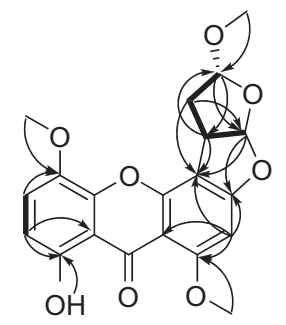

${ }^{1} \mathrm{H}-{ }^{1} \mathrm{H}$ COSY

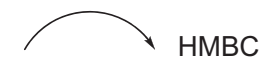

Figure 2 Key ${ }^{1} \mathrm{H}-{ }^{1} \mathrm{H}$ COSY and $\mathrm{HMBC}$ correlations of compound $\mathbf{1}$.

completely consistent with that of sterigmatocystin, which had the $\alpha$ configuration of the hemiacetal. ${ }^{12}$ Based on the coupling constants of $J_{3^{\prime} \mathrm{a}, 2^{\prime}}$ and $J_{3^{\prime} \mathrm{b}, 2^{\prime}}$, the dihedral angel between $\mathrm{H}-3^{\prime} \mathrm{a}$ and $\mathrm{H}-2^{\prime}$, and $\mathrm{H}-3^{\prime} \mathrm{b}$ and $\mathrm{H}-2^{\prime}$ should be about $20^{\circ}$ and $120^{\circ}$, respectively (Figure $3 \mathrm{c}$ ). Furthermore, the dihedral angel between $\mathrm{H}-4^{\prime}$ and $\mathrm{H}-3^{\prime}$ a should not
1)

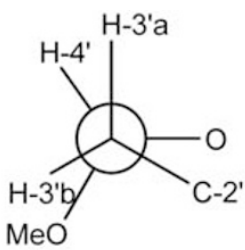

a

2)

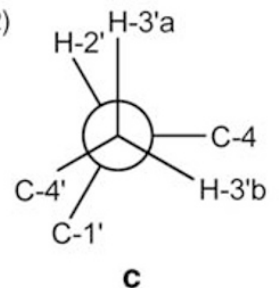

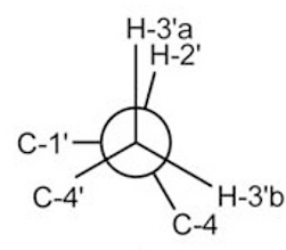

b

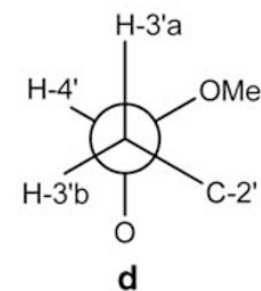

Figure 3 Newman projections of the $\beta$-configuration (1) and $\alpha$-configuration (2) of 1 and 2. (a) The bond between $C-3^{\prime}$ and $C-4^{\prime}$ of 1 ; (b) the bond between $\mathrm{C}-2^{\prime}$ and $\mathrm{C}-3^{\prime}$ of $\mathbf{1}$; (c) the bond between $\mathrm{C}-2^{\prime}$ and $\mathrm{C}-3^{\prime}$ of $\mathbf{2}$; (d) the bond between $\mathrm{C}-3^{\prime}$ and $\mathrm{C}-4^{\prime}$ of 2 .

be larger than $120^{\circ}$ was clearly proven by molecular modeling, and the dihedral angel between $\mathrm{H}-3^{\prime} \mathrm{a}$ and $\mathrm{H}-4^{\prime}$, and $\mathrm{H}-3^{\prime} \mathrm{b}$ and $\mathrm{H}-4^{\prime}$ were both close to $60^{\circ}$ (Figure $3 \mathrm{~d}$ ) based on the coupling constants of them. Finally, the $\alpha$ configuration of $4^{\prime}$-OMe in compound 2 was assigned based on the analysis above. In the NOE difference experiment of compound 2, when $\mathrm{H}-2^{\prime}(\delta 4.30$, ddd, $J=9.2,5.5,3.7 \mathrm{~Hz})$ was irradiated, the signal of $4^{\prime}$-OMe $(3.49, \mathrm{~s})$ was enhanced, which revealed the cis relationship between $\mathrm{H}-2^{\prime}$ and $4^{\prime}$-OMe. Therefore, the absolute configurations of 1 and 2 were deduced as $1^{\prime} R, 2^{\prime} S$ and $4^{\prime} R$, and $1^{\prime} R$, 2'S and 4'S, respectively. 
Oxisterigmatocystin C (3) was isolated as a pale yellow needle-like crystal. The molecular formula was determined to be $\mathrm{C}_{19} \mathrm{H}_{16} \mathrm{O}_{7}$ by HR-ESI-MS at $\mathrm{m} / z$ 357.0978 $[\mathrm{M}+\mathrm{H}]^{+}$(calcd 357.0974). The 1D NMR spectra of compound 3 (Table 1) were similar to that of compound 1 except for the absence of the signal of one methoxy group (5-OMe) and the appearance of an additional aromatic proton (H-5). So the planar structure of compound 3 was elucidated as $4^{\prime}$-methoxyl-3', $4^{\prime}$-dihydrosterigmatocystin. Because of the identical coupling constants from $\mathrm{H}-1^{\prime}$ to $\mathrm{H}-4^{\prime}$, compound 3 should also have the same absolute configurations as $1,1^{\prime} \mathrm{R}, 2^{\prime} \mathrm{S}$ and $4^{\prime} \mathrm{R}$.

\section{Cytotoxic activities}

The cytotoxicities of compounds 1-4 were evaluated in vitro against the A-549 and HL-60 cell lines using the sulforhodanine B (SRB $)^{5,13}$ and 3-(4,5-dimethylthiazol-2-yl)-2,5-diphenyl-2H-tetrazoliumbromide $(\mathrm{MTT})^{5,14}$ methods, respectively. The three new sterigmatocystin derivatives (1-3) showed no cytotoxicities on these two cancer cell lines, only compound 4 exhibited moderate cytotoxicities against the A-549 and HL-60 cell lines with the IC $_{50}$ values of 3.86 and $5.32 \mu \mathrm{M}$, respectively. This result had a significant implication that the double bond between $\mathrm{C}-3^{\prime}$ and $\mathrm{C}-4^{\prime}$ was an essential pharmacophoric moiety in sterigmatocystins, and the saturation of it would lead to the absence of cytoxicity. Similar results had been showed in recent work of Lee et al. ${ }^{1}$ who examined the effects of sterigmatocystin and dihydrosterigmatocystin.

\section{METHODS}

\section{General}

Specific rotations were obtained on a JASCO P-1020 digital polarimeter (JASCO Inc., Tokyo, Japan). IR spectra were taken on a NICOLET NEXUS 470 spectrophotometer (Beckman Coulter Inc., Brea, CA, USA) in KBr disks. ${ }^{1} \mathrm{H}-,{ }^{13} \mathrm{C}-\mathrm{NMR}$ and DEPT spectra and 2D-NMR were recorded on a JEOL JNM-ECP 600 spectrometer (JEOL Ltd., Tokyo, Japan) using TMS as internal standard and chemical shifts were recorded as $\delta$ values. ESI-MS was measured on a Q-TOF ULTIMA GLOBAL GAA076 LC mass spectrometer (Waters corporation, Milford, MA, USA). Semi-prepartive HPLC was performed using an ODS column (YMC-pak ODS-A (YMC Co. Ltd., Kyoto, Japan), $\left.10 \times 250 \mathrm{~mm}, 5 \mu \mathrm{m}, 4 \mathrm{ml} \mathrm{min}^{-1}\right)$.

\section{Fungal material}

The fungal strain A. versicolor CXCTD-06-6a was isolated from an underwater sample (depth, $800 \mathrm{~m}$ ) collected in the Pacific Ocean. The voucher specimen is deposited in our laboratory at $-20^{\circ} \mathrm{C}$. Working stocks were prepared on potato dextrose agar slants stored at $4{ }^{\circ} \mathrm{C}$.

\section{Fermentation, extraction and isolation}

Spores were directly inoculated into 500-ml Erlenmeyer flasks containing $100 \mathrm{ml}$ fermentation media (mannitol $20 \mathrm{~g}$, maltose $20 \mathrm{~g}$, glucose $10 \mathrm{~g}$, monosodium glutamate $10 \mathrm{~g}, \mathrm{KH}_{2} \mathrm{PO}_{4} 0.5 \mathrm{~g}, \mathrm{MgSO}_{4} 7 \mathrm{H}_{2} \mathrm{O} 0.3 \mathrm{~g}$, yeast extract $3 \mathrm{~g}$ and corn steep liquor $1 \mathrm{~g}$, dissolved in $1-1$ of sea water, $\mathrm{pH}$ 6.5). The flasks were incubated on a rotatory shaker $\left(165\right.$ r.p.m., $\left.28^{\circ} \mathrm{C}\right)$. After 9 days of cultivation, 301 of whole broth was filtered through cheesecloth to separate the broth supernatant and mycelia. The former was extracted with ethyl acetate, whereas the latter was extracted with acetone. The acetone extract was evaporated under reduced pressure to afford an aqueous solution, and then extracted with ethyl acetate. The two ethyl acetate extracts were combined and concentrated under reduced pressure to give a crude extract $(35.0 \mathrm{~g})$.

The crude extract (35.0 g) was subjected to a silica gel (300-400 mesh) CC and was separated into five fractions (Fr.1-Fr.5) using a step gradient elution of petroleum ether $/ \mathrm{CHCl}_{3}$ and $\mathrm{CHCl}_{3} / \mathrm{CH}_{3} \mathrm{OH}$. The active fraction, Fr.3, eluted with 100:1 $\mathrm{CHCl}_{3} / \mathrm{MeOH}$ was fractionated on a silica gel CC using a step gradient elution of petroleum ether/acetone and was separated into five fractions (Fr.3.1-Fr.3.5). Fr.3.2 was subjected to Sephadex LH-20 CC (GE
Healthcare, Uppsala, Sweden) using $\mathrm{CHCl}_{3} / \mathrm{CH}_{3} \mathrm{OH}$ (50:50) as the eluting solvent, silica gel CC using elution of petroleum ether/acetone (10:1) and RP-18 semi-preparative HPLC $\left(80: 20 \mathrm{CH}_{3} \mathrm{OH} / \mathrm{H}_{2} \mathrm{O}, 4 \mathrm{ml} \mathrm{min}^{-1}\right)$ to give compound 3 ( $3.0 \mathrm{mg}$, Rt $6.1 \mathrm{~min}$ ). Fr.3.3 was separated on Sephadex LH-20 CC using $\mathrm{CHCl}_{3} / \mathrm{CH}_{3} \mathrm{OH}(50: 50)$ as the eluting solvent and silica gel CC using elution of petroleum ether/acetone (80:20) to afford four fractions (Fr.3.3.2.1-Fr.3.3.2.4). Fr.3.3.2.1 was further purified by RP-18 semi-preparative

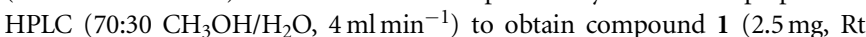
$9.0 \mathrm{~min}$ ), compound 2 (2.3 mg, Rt $11.2 \mathrm{~min})$ and compound 4 (7.8 mg, Rt $10.5 \mathrm{~min})$, respectively.

\section{Physico-chemical properties}

Oxisterigmatocystin A (1): pale yellow needle-like crystals, $[\alpha]_{\mathrm{D}}^{25}-297.9$ (c 0.1, $\mathrm{CHCl}_{3}$ ), UV (HPLC, mobile phase) $\lambda_{\max } \mathrm{nm}: 222,244,269,327$, IR (KBr) cm ${ }^{-1}: 2957,2927,2851,1593,1488,1244,1059,811,{ }^{1} \mathrm{H}-\mathrm{NMR}\left(\mathrm{CDCl}_{3}\right.$, $600 \mathrm{MHz})$ and ${ }^{13} \mathrm{C}-\mathrm{NMR}\left(\mathrm{CDCl}_{3}, 150 \mathrm{MHz}\right)$, see Table 1 , HR-ESI-MS $\mathrm{m} / \mathrm{z}$ : $387.1067[\mathrm{M}+\mathrm{H}]^{+}$(calcd for $\mathrm{C}_{20} \mathrm{H}_{19} \mathrm{O}_{8}: 387.1080$ ).

Oxisterigmatocystin B (2): pale yellow needle-like crystals, $[\alpha]_{\mathrm{D}}^{25}-79.8(c 0.1$, $\mathrm{CHCl}_{3}$ ), UV (HPLC, mobile phase) $\lambda_{\max } \mathrm{nm}: 224,244,269,323, \mathrm{IR}(\mathrm{KBr})$ $\mathrm{cm}^{-1}: 2951,2923,2857,1588,1490,1246,1047,805,{ }^{1} \mathrm{H}-\mathrm{NMR}\left(\mathrm{CDCl}_{3}\right.$, $600 \mathrm{MHz})$ and ${ }^{13} \mathrm{C}-\mathrm{NMR}\left(\mathrm{CDCl}_{3}, 150 \mathrm{MHz}\right)$, see Table 1 , HR-ESI-MS $\mathrm{m} / \mathrm{z}$ : $387.1098[\mathrm{M}+\mathrm{H}]^{+}$(calcd for $\mathrm{C}_{20} \mathrm{H}_{19} \mathrm{O}_{8}: 387.1080$ ).

Oxisterigmatocystin $\mathrm{C}(3)$ : pale yellow needle-like crystals, $[\alpha]_{D}^{25}-128.2$ ( $c$ 0.1, $\mathrm{CHCl}_{3}$ ), UV (HPLC, mobile phase) $\lambda_{\max } \mathrm{nm}: 223,241,320$, IR (KBr) $\mathrm{cm}^{-1}: 2966,2920,2850,1582,1458,1235,1062,976,979,823,{ }^{1} \mathrm{H}-\mathrm{NMR}$ $\left(\mathrm{CDCl}_{3}, 600 \mathrm{MHz}\right)$ and ${ }^{13} \mathrm{C}-\mathrm{NMR}\left(\mathrm{CDCl}_{3}, 150 \mathrm{MHz}\right)$, see Table 1, HR-ESI-MS $m / z: 357.0978[\mathrm{M}+\mathrm{H}]^{+}$(calcd for $\left.\mathrm{C}_{19} \mathrm{H}_{17} \mathrm{O}_{7}, 357.0974\right)$.

5-methoxysterigmatocystin (4): pale yellow needle-like crystals, $[\alpha]_{\mathrm{D}}^{25}-270.2$ (c $0.1, \mathrm{CHCl}_{3}$ ).

\section{In vitro cytotoxicity assays}

In the MTT assay, the cell line was grown in RPMI-1640 supplemented with $10 \%$ fetal bovine serum under a humidified atmosphere of $5 \% \mathrm{CO}_{2}$ and $95 \%$ air at $37^{\circ} \mathrm{C}$. Cell suspensions $(200 \mu \mathrm{l})$ at a density of $5 \times 10^{4}$ cells per $\mathrm{ml}$ were plated in 96-well microtiter plates and incubated for $24 \mathrm{~h}$. The test compound solutions $(2 \mu \mathrm{l}$ in $\mathrm{MeOH})$ at different concentrations were added to each well and further incubated for $72 \mathrm{~h}$ under the same conditions. MTT solution $(20 \mu \mathrm{l}$ of a $5 \mathrm{mg} \mathrm{ml}^{-1}$ solution in RPMI-1640 medium) was added to each well and incubated for $4 \mathrm{~h}$. An old medium $(150 \mu \mathrm{l})$ containing MTT was then gently replaced by DMSO and pipetted to dissolve any formazan crystals formed. Absorbance was then determined on a SPECTRA MAX PLUS plate reader (Molecular Devices, Sunnyvale, CA, USA) at $540 \mathrm{~nm}$.

In the SRB assay, cell suspensions $(200 \mu \mathrm{l})$ were plated in 96 -cell plates at a density of $2 \times 10^{5}$ cells per $\mathrm{ml}$. Then the test compound solutions $(2 \mu \mathrm{l}$ in $\mathrm{MeOH}$ ) at different concentrations were added to each well and further incubated for $24 \mathrm{~h}$. Following drug exposure, the cells were fixed with $12 \%$ TCA and the cell layer was stained with $0.4 \%$ SRB. The absorbance of SRB solution was measured at $515 \mathrm{~nm}$. Dose-response curves were generated and the $\mathrm{IC}_{50}$ values were calculated from the linear portion of log dose-response curves.

\section{ACKNOWLEDGEMENTS}

This work was financially supported by the Chinese National Science Fund (No. 30772640 and 30973627) and the Shandong Provincial Natural Science Fund (No. ZR2009CZ016). The antitumor assay was performed at the Shanghai Institute of Materia Medica, Chinese Academy of Sciences. We also thank Dr Wendy Strangman of UBC for the advice on the manuscript.

1 Lee, Y. et al. Bioactive metabolites from the sponge-derived fungus Aspergillus versicolor. Arch. Pharm. Res. 33, 231-235 (2010).

$2 \mathrm{Li}, \mathrm{G}$. et al. Brevianamide J, a new indole alkaloid dimer from fungus Aspergillus versicolor. Org. Lett. 11, 3714-3717 (2009).

3 Belofsky, G. N., Jensen, P. R., Renner, M. K. \& Fenical, W. New cytotoxic sesquiterpenoid nitrobenzoyl esters from a marine isolate of the fungus Aspergillus versicolor. Tetrahedron 54, 1715-1724 (1998). 
4 Fremlin, L. J., Piggott, A. M., Lacey, E. \& Capon, R. J. Cottoquinazoline A and cotteslosins $\mathrm{A}$ and $\mathrm{B}$, metabolites from an Australian marine-derived strain of Aspergillus versicolor. J. Nat. Prod. 72, 666-670 (2009).

5 Cai, S. et al. Two new indole alkaloids from the marine-derived bacterium Aeromonas sp. CB101. Helv. Chim. Acta. 93, 791-795 (2010).

$6 \mathrm{Li}$, D. et al. Trisorbicillinone A, a novel sorbicillin trimer, from a deep sea fungus, Phialocephala sp. FL30r. Tetrahedron Lett. 48, 5235-5238 (2007).

$7 \mathrm{Li}$, D. et al. Two new bisorbicillinoids isolated from a deep sea fungus, Phialocephala sp. FL30r. J. Antibiot. 60, 317-320 (2007).

$8 \mathrm{Du}$, L. et al. New alkaloids and diterpenes from a deep ocean sediment derived fungus Penicillium sp. Tetrahedron 65, 1033-1039 (2009).

9 Du, L. et al. Alkaloids from a deep ocean sediment-derived fungus Penicillium sp. and their antitumor activities. J. Antibiot. 63, 165-170 (2010).
10 Shao, C. et al. ${ }^{1} \mathrm{H}$ and ${ }^{13} \mathrm{C}$ NMR assignments for two anthraquinones and two xanthones from the mangrove fungus (ZSUH-36). Magn. Reson. Chem. 45, 434438 (2007).

11 Zhu, F. \& Lin, Y. Three xanthones from a marine-derived mangrove endophytic fungus. Chem. Nat. Comp. 43, 132-135 (2007).

12 Ashley, D. L., Orti, D. L. \& Hill, R. H. Proton nuclear magnetic resonance evidence for two configurations of the hemiacetals of aflatoxin B1 and sterigmatocystin. J. Agric. Food Chem. 35, 782-785 (1987).

13 Skehan, P. et al. New colorimetric cytotoxicity assay for anticancer-drug screening. J. Nat/ Cancer Inst. 82, 1107-1112 (1990).

14 Mosmann, T. Rapid colorimetric assay for cellular growth and survival: application to proliferation and cytotoxicity assays. J. Immunol. Methods 65, 55-63 (1983). 